\title{
Comparison of porcine thorax to gelatine blocks for wound ballistics studies
}

\author{
A. Mabbott ${ }^{1}$ - D. J. Carr ${ }^{1}$ - S. Champion ${ }^{2}$ - C. Malbon $^{3}$
}

Received: 19 October 2015 / Accepted: 15 December 2015 / Published online: 4 February 2016

(C) The Author(s) 2016. This article is published with open access at Springerlink.com

\begin{abstract}
Tissue simulants are typically used in ballistic testing as substitutes for biological tissues. Many simulants have been used, with gelatine amongst the most common. While two concentrations of gelatine (10 and $20 \%$ ) have been used extensively, no agreed standard exists for the preparation of either. Comparison of ballistic damage produced in both concentrations is lacking. The damage produced in gelatine is also questioned, with regards to what it would mean for specific areas of living tissue. The aim of the work discussed in this paper was to consider how damage caused by selected pistol and rifle ammunition varied in different simulants. Damage to gelatine blocks 10 and $20 \%$ in concentration were tested with $9 \mathrm{~mm}$ Luger $(9 \times 19$ full metal jacket; FMJ $)$ rounds, while damage produced by .223 Remington $(5.56 \times 45$ Federal Premium ${ }^{\circledR}$ Tactical ${ }^{\circledR}$ Bonded ${ }^{\circledR}$ ) rounds to porcine thorax sections (skin, underlying tissue, ribs, lungs, ribs, underlying tissue, skin; backed by a block of $10 \%$ gelatine) were compared
\end{abstract}

Electronic supplementary material The online version of this article (doi:10.1007/s00414-015-1309-9) contains supplementary material, which is available to authorized users.

D. J. Carr

d.j.carr@cranfield.ac.uk

1 Impact and Armour Group, Centre for Defence Engineering, Cranfield University at the Defence Academy of the United Kingdom, Shrivenham SN6 8LA, UK

2 Weapons and Vehicle Systems Group, Centre for Defence Engineering, Cranfield University at the Defence Academy of the United Kingdom, Shrivenham SN6 8LA, UK

3 Mechanical Engineering, Material Science and Civil Engineering, Centre for Applied Science and Technology, Home Office Science, Woodcock Hill, Sandridge, St Albans, Hertfordshire AL4 9HQ, UK to 10 and $20 \%$ gelatine blocks. Results from the .223 Remington rifle round, which is one that typically expands on impact, revealed depths of penetration in the thorax arrangement were significantly different to $20 \%$ gelatine, but not $10 \%$ gelatine. The level of damage produced in the simulated thoraxes was smaller in scale to that witnessed in both gelatine concentrations, though greater debris was produced in the thoraxes.

Keywords Tissue simulants $\cdot$ Pistol $\cdot$ Rifle $\cdot 10$ and $20 \%$ gelatine

\section{Introduction}

Many tissue simulants have been and continue to be used in the study of ballistics as substitutes for biological tissues such as skin, muscles and organs, e.g. $[1,2]$. Perhaps the most widely used simulants are gelatine and glycerine soap [3]. Gelatine is typically utilised in either a $10 \%$, e.g. $[1,2,4-8]$ or $20 \%$, e.g. [9-11] (by mass) concentration, conditioned at 4 and $10{ }^{\circ} \mathrm{C}$, respectively. Early studies found that using gelatine produced similar penetration depths for a range of ammunition to those observed in soft tissue, while demonstrating the mechanics of the temporary and permanent cavities that resulted from a ballistic impact $[9,12,13]$. Gelatine is translucent in nature meaning a projectiles' behaviour and the exact path and placement of projectiles and/or fragments can be easily viewed and analysed [1, 7, 14, 15]. However, no agreement as to which gelatine concentration to utilise has been reached, nor a standard method for preparation $[2,16]$. Work in the open source literature which uses and compares how both gelatine concentrations fare in ballistic testing is limited, e.g. $[11,12,17]$. 
In a gunshot wound in living tissue, three zones are used to describe the areas of the wound, the central zone, caused by the direct crushing and lacerating of tissue by the projectile, surrounded by the second and third zones, contusion and concussion, respectively [18-20]. The outer two zones are believed to be the result of the temporary cavitation process, with the zone of contusion consisting of non-viable tissue, and the concussion zone showing damaged tissue capable of recovering [21]. Variables including shape, size, likelihood of fragmentation, mass, velocity and available kinetic energy of the projectile, together with the variable physical characteristics of the living target, all have an effect on the damage that is produced [20, 22-24].

Questions still remain regarding how damage recorded in tissue simulants compares to damage in living tissue and to specific areas of a human body. Although gelatine has been shown to be a close match for thigh muscle of both humans and pigs when comparing densities [2, 21, 25, 26], as well as $10 \%$ gelatine being shown to produce depths of penetration that are within $3 \%$ of living porcine muscle $[4,5]$, a typical priority area on a human target is not the thigh muscle. An area of the body that is more commonly targeted during a ballistic attack is the thorax, which is composed of many differing materials (skin, muscle, bone, heart, lungs, blood vessels, fatty deposits, nerves, etc.) and is thus very different to the composition of thigh muscle.

Breeze et al. [27] found significantly different depths of penetrations were produced in the thorax and abdomen of pig cadavers compared to $20 \%$ gelatine, when testing three different fragment simulating projectiles (FSPs). The outcome was attributed to the anatomical complexity and multiple tissue interfaces of the thorax and abdominal regions.

The aim of the work discussed in this paper was to consider how damage to a tissue simulant compares to damage observed in a thorax after ballistic attack. Following previous work [28, 29], porcine thoracic walls were utilised either side of a pair of lungs to simulate a thorax, with results being compared to 10 and $20 \%$ gelatine blocks.

\section{Materials and methods}

\section{Materials}

Gelatine from a single manufacturing batch and with a Bloom strength of 225-265 (type 3 ballistic photographic grade gelatine $^{1}$ ) was used to manufacture 10 and $20 \%$ gelatine blocks. The moulds in which the gelatine blocks were manufactured measured $250 \mathrm{~mm}(\mathrm{w}) \times 250 \mathrm{~mm}$ (h) $\times 500 \mathrm{~mm}$ (l), with both longer sides tapered $1^{\circ}$ to facilitate set gelatine block removal. Both gelatine concentrations

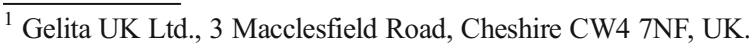

were left to set at room temperature $\left(\sim 18{ }^{\circ} \mathrm{C} \pm 3{ }^{\circ} \mathrm{C}\right)$ for $24 \mathrm{~h}$, before being placed in a refrigerator for a further $24 \mathrm{~h} ; 10 \%$ blocks at $4{ }^{\circ} \mathrm{C}, 20 \%$ blocks at $10{ }^{\circ} \mathrm{C}$ prior to use.

Samples of porcine thoracic walls ${ }^{2}$ (consisting of the ribs, intercostal muscles, underlying tissue and skin; vertebra and the sternum removed) and sets of porcine lung pairs complete with trachea were collected and kept refrigerated one day prior to testing. Samples were brought up to room temperature for at least $12 \mathrm{~h}$ before testing $(\sim 18$ $\left.\pm 3{ }^{\circ} \mathrm{C}\right)$. The samples used were all of food-grade standard and fit for human consumption; consequently, there were no ethical concerns raised for this study

Two ammunition types were used for testing:

(i) .223 Remington $\left(5.56 \times 45 ; 62\right.$ grain; Federal Premium ${ }^{\circledR}$ Tactical ${ }^{\circledR}$ Bonded $\left.{ }^{\circledR}\right)$

(ii) $9 \mathrm{~mm}$ Luger $(9 \times 19 \mathrm{FMJ} ; 124$ grain; DM11 A1B2 $)$ (Fig. 1)

The two types of ammunition cover both a rifle and a pistol round, both rounds are designed to interact differently with targets. The .223 Remington rifle round has an exposed tip and typically expands on impact, while the $9 \mathrm{~mm}$ Luger pistol round does not typically breakup or fragment, but does have a tendency to yaw within targets.

\section{Methods—gelatine testing}

All testing was performed at the Small Arms Experimental Range at Cranfield University. The targets were placed $10 \mathrm{~m}$ down range from the end of the muzzle. An Enfield Number 3 Proof Housing, with the appropriate barrel fitted, was used to fire each ammunition type. Ten shots with each ammunition type was carried out $(n=10)$. A new gelatine block was used for every shot with the .223 Remington ammunition, while two or three rounds of the $9 \mathrm{~mm}$ Luger ammunition were fired into each gelatine block, ensuring the tracts did not overlay. The impact velocities were recorded using a Weibel W-700 Doppler radar, and the impact event was recorded using a Phantom V12 high-speed video camera $(41,025 \mathrm{fps}, 5 \mu \mathrm{s}$ exposure time and $512 \times 256$ frame resolution).

Prior to testing, a 5.5-mm-diameter steel BB was fired at $\sim 750 \mathrm{~m} / \mathrm{s}$ from a distance of $10 \mathrm{~m}$ into the top right of each gelatine block. The velocity and depth of penetration of these shots were measured and compared with results collected from previously published depth of penetration testing to ensure only calibrated gelatine blocks were used for testing [17].

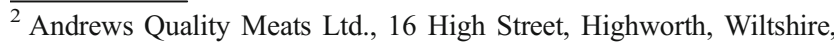
SN6 7AG, UK.
} 


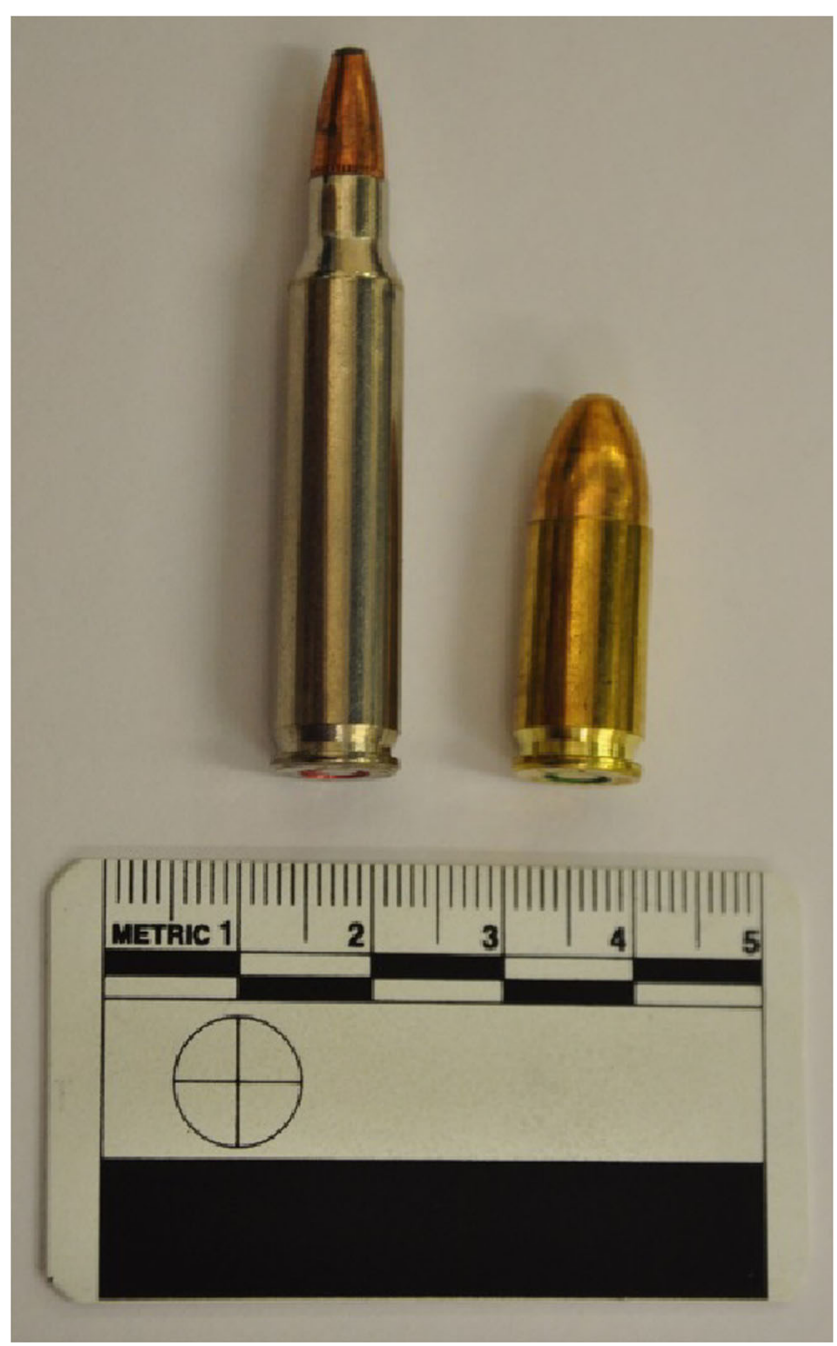

Fig. 1.223 Remington $\left(5.56 \times 45 ; 62\right.$ grain; Federal Premium ${ }^{\circledR}$ Tactical ${ }^{\circledR}$ Bonded $\left.{ }^{\circledR}\right)($ left $)$ and $9 \mathrm{~mm}$ Luger $(9 \times 19 \mathrm{FMJ} ; 124$ grain; DM11 A1B2) (right)

\section{Methods-porcine thorax testing}

The porcine samples were arranged $10 \mathrm{~m}$ down range from the end of the muzzle to simulate a thorax; a porcine thoracic wall was placed as the anterior of the target (skin facing muzzle), then a set of lungs positioned in relation to the thoracic wall as they would be anatomically in a human, followed by another thoracic wall (skin facing away from muzzle) (Fig. 2). In order to ensure that a complete bullet tract was captured, a $10 \%$ gelatine block $500 \mathrm{~mm}$ in length was placed adjacent to and in contact with the posterior thoracic wall. An Enfield Number 3 Proof Housing, with the appropriate barrel fitted, was used to fire each ammunition type. Each individual shot was aimed with the goal of striking: a rib within the anterior thoracic wall, either the left or right lung, and a rib in the posterior thoracic wall, before capturing the rest of the tract in a gelatine block (calibrated as above). Shots that were fired onto the same thoracic sections were located to ensure damaged areas did

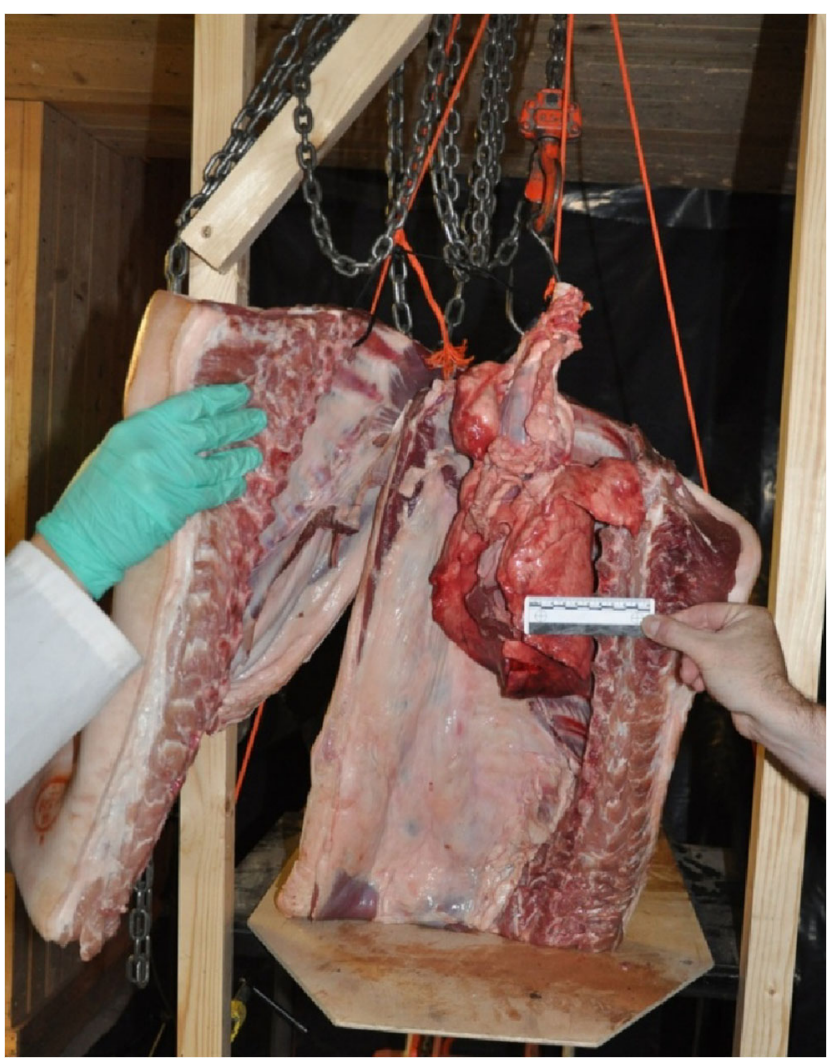

Fig. 2 Typical set up showing the arrangement of the thoracic walls and lungs

not overlap. The impact velocities were recorded using a Weibel W-700 Doppler radar, and the impact event was recorded using a Phantom V12 high-speed video camera (21, $005 \mathrm{fps}, 5 \mu$ s exposure time and $512 \times 512$ frame resolution). Ten shots in total were carried out $(n=7$ for .223 Remington; $n=3$ for $9 \mathrm{~mm}$ Luger).

\section{Analysis}

\section{Gelatine blocks}

Analysis of the high-speed footage was carried out using Phantom software (Vision Research, Phantom Camera Control Application 2.5) (Fig. 3). Each file was calibrated by using a known length visible in the image, converting pixels present in the image to a dimension in millimeters. Once calibrated, it was possible to take measurements that included the diameter of the temporary cavity at its largest, and the distance (from the entry point of the projectile in the gelatine block) to where this occurred. Both these measurements were taken using the PCC 2.5 software. It was also possible to locate the position and the number of times the $9 \mathrm{~mm}$ Luger rounds yawed within the target.

The gelatine blocks were dissected after testing by cutting along the permanent tract using a knife. Lead debris present in 


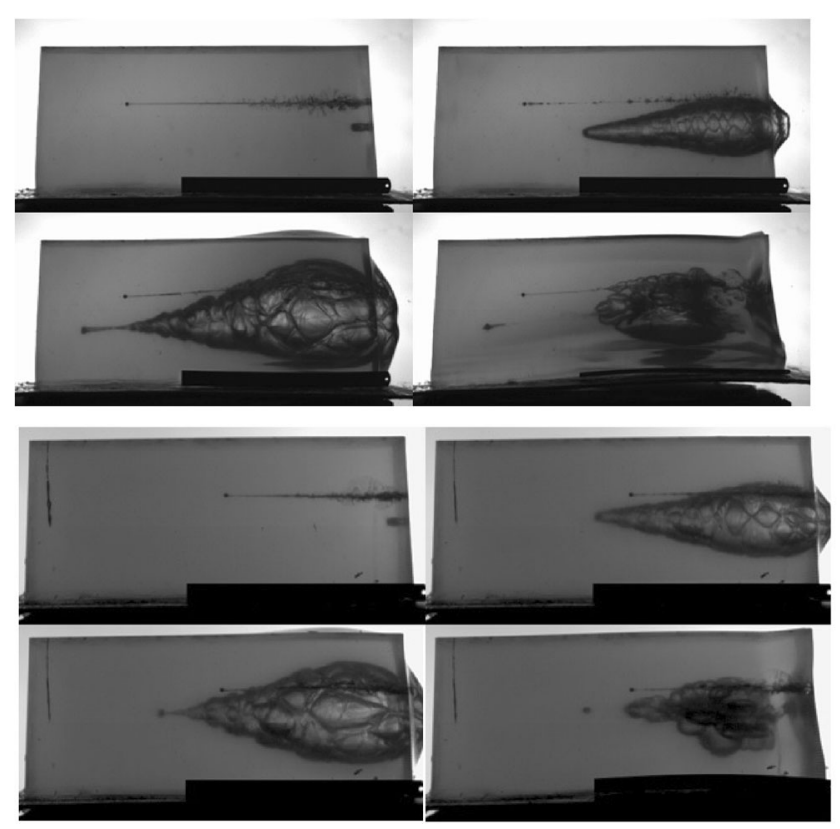

Fig. 3 High-speed stills of a typical .223 Remington impact into $10 \%$ gelatine (top four images) and $20 \%$ gelatine (bottom four images)

the cavities was noted, photographed, ${ }^{3}$ removed and bagged. Measurements of the permanent cavities (as indicated by damaged area / fissures) produced in the gelatine blocks were taken, specifically neck length, 'body' length, 'body' width, 'body' height and (when possible) distance to projectile. From the body dimensions, the formula for calculating the volume of an ellipsoid was used to calculate a representation of the maximal volume of the damage the permanent cavity created:

$V_{\text {ellipsoid }}=\frac{4}{3} \pi l w h$,

where $l, h$ and $w$ are the length, width and height body dimensions, all halved. Length and height of fissures present in the gelatine blocks were also recorded. From these measurements, the area of each individual fissure was calculated using the formula for an ellipse, divided by two as a fissure was only half of an ellipse:

$A_{\text {ellipse }}=\frac{\pi a b}{2}$,

where $a$ and $b$ are the respective length and height measurements of a fissure, halved. A total fissure area for each shot was calculated by adding together the areas of the individual fissures.

Summary statistics (mean (x), standard deviation (s.d.) and coefficient of variation (CV)) were calculated for the fissure and the permanent cavity data sets, as well as the data from the high-speed video analysis. Analysis of variance (ANOVA) was used to determine when significant differences between the two gelatine concentrations occurred (SPSS Statistics

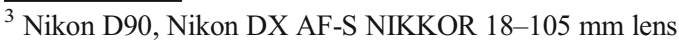

22.0). Normality of data and equality of variance were checked for each data set.

\section{Porcine tissue}

Post firing analysis of the porcine thoracic walls and lungs was performed after all shots had been completed. Measurements of the entrance and exit wounds of each shot were taken from every perforated section of each simulated thoracic cavity (i.e. the front thoracic wall, the lung and the rear thoracic wall). Any projectile and/or bone fragments found were photographed, weighed ${ }^{4}$ and recovered, before dissection of the samples took place. Further fragments found from exploration of the damage were also photographed, recovered and weighed.

Post firing analysis of the gelatine blocks located behind the porcine tissue consisted of cutting along the length of the permanent cavity, before measurements of the cavity were taken. When present, the projectile and any projectile and/or bone fragments were photographed, recovered and weighed.

ANOVA and Tukey analysis were used to determine if there were significant differences amongst the distance to projectile data obtained from firing .223 Remington projectiles at the porcine thoracic target arrangement, $10 \%$ gelatine targets and $20 \%$ gelatine targets (SPSS Statistics 22.0). Normality of data and equality of variance were checked for each data set.

\section{Results}

\section{.223 Remington projectiles}

Comparing the two gelatine concentrations revealed that the mean measurements of both the temporary and permanent cavities in $10 \%$ gelatine were larger than those collected from cavities in $20 \%$ gelatine blocks (Table 1). The spread of the data was also typically larger for the measurements collected from $10 \%$ gelatine (Table 1). Metallic deposits were found within all targets, none greater than $0.5 \mathrm{~mm}$ in size.

Analysis of variance on the temporary cavity measurements revealed that the distance to the maximum expansion in both concentrations of gelatine was not significantly different $\left(F_{1,18}=1.12, p=\mathrm{NS}\right)$, though the mean distance was numerically greater in $10 \%$ gelatine (Table 1 ). Conversely, the maximum expansion (diameter) reached by the temporary cavity was significantly affected by gelatine concentration $\left(F_{1,18}=144.25, p \leq 0.001\right)$. The mean temporary cavity was larger in $10 \%$ gelatine $($ mean $=178.1 \mathrm{~mm}$, s.d. $=4.0 \mathrm{~mm}$ ), when compared to the mean temporary cavity diameter in $20 \%$ gelatine $($ mean $=157.6 \mathrm{~mm}$, s.d. $=3.6 \mathrm{~mm})$.

${ }^{4}$ A2204 Oxford Balance; Analytical products Ltd., Oxford, England, OX3 8ST. Developed, manufactured and tested in compliance with ISO 9001. 
Table 1 Results collected from interactions between .223 Remington and (a) 10 and (b) $20 \%$ gelatine

\begin{tabular}{|c|c|c|c|c|c|c|c|c|c|}
\hline Shot & Impact & \multirow{2}{*}{\multicolumn{2}{|c|}{$\begin{array}{lc}\text { Temporary cavity } & \\
\text { Distance to } & \text { Maximum } \\
\text { maximum } & \text { diameter } \\
\text { expansion } & (\mathrm{mm}) \\
(\mathrm{mm}) & \end{array}$}} & \multicolumn{5}{|c|}{ Permanent cavity } & \multirow{2}{*}{$\begin{array}{l}\text { Distance to } \\
\text { projectile } \\
(\mathrm{mm})\end{array}$} \\
\hline no. & $\begin{array}{l}\text { velocity } \\
(\mathrm{m} / \mathrm{s})\end{array}$ & & & $\begin{array}{l}\text { Neck } \\
\text { length } \\
(\mathrm{mm})\end{array}$ & $\begin{array}{l}\text { Body } \\
\text { length } \\
(\mathrm{mm})\end{array}$ & $\begin{array}{l}\text { Body } \\
\text { height } \\
\text { (mm) }\end{array}$ & $\begin{array}{l}\text { Body } \\
\text { width } \\
(\mathrm{mm})\end{array}$ & $\begin{array}{l}\text { Total } \\
\quad \text { fissure } \\
\text { area } \\
\left(\mathrm{mm}^{2}\right)\end{array}$ & \\
\hline 1 & 843 & 85 & 178 & 0 & 300 & 95 & 105 & 47,000 & 454 \\
\hline 2 & 844 & 91 & 180 & 0 & 280 & 100 & 110 & 40,000 & 425 \\
\hline 3 & 842 & 75 & 177 & 2 & 260 & 100 & 115 & 45,200 & 425 \\
\hline 4 & 852 & 77 & 171 & 0 & 325 & 90 & 105 & 76,000 & 423 \\
\hline 5 & 853 & 100 & 174 & 0 & 330 & 105 & 105 & 81,300 & 423 \\
\hline 6 & 852 & 99 & 182 & 0 & 340 & 145 & 100 & 59,300 & 420 \\
\hline 7 & 853 & 102 & 179 & 0 & 290 & 140 & 95 & 85,000 & 402 \\
\hline 8 & 839 & 85 & 178 & 0 & 320 & 110 & 150 & 77,500 & 430 \\
\hline 9 & 844 & 93 & 184 & 0 & 315 & 110 & 130 & 67,400 & 428 \\
\hline 10 & 854 & 75 & 173 & 0 & 325 & 125 & 130 & 111,000 & 429 \\
\hline Mean & 847.6 & 88.7 & 178.0 & $\mathrm{~N} / \mathrm{A}$ & 308.5 & 112.0 & 114.5 & 69,000 & 425.9 \\
\hline s.d. & 5.7 & 10.3 & 4.0 & N/A & 25.3 & 18.7 & 17.1 & 22,000 & 12.7 \\
\hline $\begin{array}{l}\mathrm{CV} \\
(\%)\end{array}$ & 0.7 & 11.7 & 2.2 & N/A & 8.2 & 16.7 & 14.9 & 31.7 & 3.0 \\
\hline Min & 839 & 75 & 171 & 0 & 260 & 90 & 95 & 40,000 & 402 \\
\hline Max & 854 & 102 & 184 & 2 & 340 & 145 & 150 & 111,000 & 454 \\
\hline \multicolumn{10}{|c|}{ (b) $20 \%$ results } \\
\hline \multirow{2}{*}{$\begin{array}{l}\text { Shot } \\
\text { no. }\end{array}$} & \multirow{2}{*}{$\begin{array}{l}\text { Impact } \\
\text { velocity } \\
(\mathrm{m} / \mathrm{s})\end{array}$} & \multirow[b]{2}{*}{$\begin{array}{l}\text { Temporary cavity } \\
\text { Distance to } \\
\text { maximum } \\
\text { expansion } \\
(\mathrm{mm})\end{array}$} & & \multicolumn{2}{|c|}{ Permanent cavity } & & & & Distance to \\
\hline & & & $\begin{array}{l}\text { Maximum } \\
\text { diameter } \\
(\mathrm{mm})\end{array}$ & $\begin{array}{l}\text { Neck } \\
\text { length } \\
(\mathrm{mm})\end{array}$ & $\begin{array}{l}\text { Body } \\
\text { length } \\
(\mathrm{mm})\end{array}$ & $\begin{array}{l}\text { Body } \\
\text { height } \\
\text { (mm) }\end{array}$ & $\begin{array}{l}\text { Body } \\
\text { width } \\
(\mathrm{mm})\end{array}$ & $\begin{array}{l}\text { Total } \\
\quad \text { fissure } \\
\text { area } \\
\left(\mathrm{mm}^{2}\right)\end{array}$ & $\begin{array}{l}\text { projectile } \\
(\mathrm{mm})\end{array}$ \\
\hline 1 & 839 & 88 & 161 & 5 & 240 & 95 & 85 & 58,000 & 315 \\
\hline 2 & 842 & 88 & 158 & 1 & 260 & 100 & 85 & 42,000 & 316 \\
\hline 3 & 842 & 86 & 163 & 1 & 270 & 115 & 110 & 36,900 & 306 \\
\hline 4 & 844 & 83 & 153 & 0 & 260 & 110 & 110 & 53,300 & 295 \\
\hline 5 & 845 & 83 & 163 & 1 & 275 & 115 & 100 & 49,100 & 287 \\
\hline 6 & 844 & 88 & 158 & 3 & 245 & 130 & 120 & 56,600 & 280 \\
\hline 7 & 852 & 80 & 155 & 1 & 260 & 110 & 120 & 37,600 & 289 \\
\hline 8 & 846 & 80 & 154 & 2 & 230 & 85 & 110 & 50,000 & 283 \\
\hline 9 & 855 & 90 & 155 & 0 & 260 & 115 & 95 & 57,000 & 299 \\
\hline 10 & 841 & 84 & 156 & 0 & 245 & 95 & 110 & 62,000 & 292 \\
\hline Mean & 845.0 & 85.0 & 157.6 & 1.4 & 254.5 & 107.0 & 104.5 & 50,000 & 296.2 \\
\hline s.d. & 5.0 & 3.5 & 3.6 & 1.6 & 14.0 & 13.2 & 12.8 & 8,800 & 12.7 \\
\hline $\begin{array}{l}\mathrm{CV} \\
(\%)\end{array}$ & 0.6 & 4.1 & 2.3 & 112.7 & 5.5 & 12.3 & 12.2 & 17.4 & 4.3 \\
\hline Min & 839 & 80 & 153 & 0 & 230 & 85 & 85 & 36,900 & 280 \\
\hline Max & 855 & 90 & 163 & 5 & 275 & 130 & 120 & 62,000 & 316 \\
\hline
\end{tabular}

From the permanent cavity data collected, analysis of variance could not be carried out on neck length due to there being only one measurement in $10 \%$ gelatine. For body length, however, gelatine concentration had a significant effect $\left(F_{1,18}=34.88, p \leq 0.001\right)$. The mean body length was longer in $10 \%$ gelatine $($ mean $=308.5 \mathrm{~mm}$, s.d. $=25.3 \mathrm{~mm}$ ) compared to $20 \%$ gelatine $($ mean $=254.5 \mathrm{~mm}$, s.d. $=14.0 \mathrm{~mm}$ ). The representation of the maximum ellipsoid volume was significantly different in both concentrations of gelatine $\left(F_{1,18}=9.08, p \leq 0.01\right)$. The mean volume was larger in $10 \%$ compared to $20 \%$ gelatine $(10 \%$ gelatine mean $=2$, $100,000 \mathrm{~mm}^{3}$, s.d. $=50,000 \mathrm{~mm}^{3} ; 20 \%$ gelatine mean $=1$, $500,000 \mathrm{~mm}^{3}$, s.d. $=330,000 \mathrm{~mm}^{3}$ ). Concentration of gelatine also significantly affected fissure area of the permanent cavity 
$\left(F_{1,18}=6.36, p \leq 0.05\right)$. The mean area in $20 \%$ gelatine (mean $=50,000 \mathrm{~mm}^{2}$, s.d. $=8700 \mathrm{~mm}^{2}$ ) was less than the mean fissure area in $10 \%$ gelatine $\left(\right.$ mean $=69,000 \mathrm{~mm}^{2}$, s.d. $=22,000 \mathrm{~mm}^{2}$ ).

The distance .223 Remington projectiles penetrated within the different gelatine concentrations was significantly different $\left(F_{1,18}=524.51, p \leq 0.001\right)$. The mean distance in $10 \%$ gelatine $($ mean $=425.9 \mathrm{~mm}$, s.d. $=12.7 \mathrm{~mm})$ was $129.7 \mathrm{~mm}$ longer than the mean distance to projectile in $20 \%$ gelatine (mean $=296.2 \mathrm{~mm}$, s.d. $=12.7 \mathrm{~mm}$ ).

\section{.223 Remington simulated thorax testing}

Seven shots were carried out into the simulated thorax targets (Table 2). Tissue and metallic debris from all porcine samples was collected and weighed (see electronic supplementary material).

In order to compare the distances to which .223 Remington projectiles penetrated the simulated thoraxes with the distances produced in both gelatine concentrations, only the first seven shots into the respective gelatine blocks were used for ANOVA, ensuring equality of sample size. Target material had a significant effect on the distance to the projectiles travelled $\left(F_{2,18}=146.54, p \leq 0.001\right)$. Tukey's HSD multiple comparison test indicated the three different target types resulted in three varying levels of distances travelled. Distance was greatest in the simulated thorax cavity arrangement $($ mean $=460.0 \mathrm{~mm}$, s.d. $=24.5 \mathrm{~mm})$; mean distance in $10 \%$ gelatine was slightly shorter $($ mean $=424.6 \mathrm{~mm}$, s.d. $=15.2)$. Mean distance in $20 \%$ gelatine was over $160 \mathrm{~mm}$ shorter compared to the thoracic cavity (mean $=298.3 \mathrm{~mm}$, s.d. $=14.2 \mathrm{~mm})($ Tables 1 and 2). Comparison of the respective CVs revealed that the variability of the thoracic cavity was similar to those produced in the gelatine targets.

Studying the strike location through the thoracic cavity targets revealed that shot 4 , which resulted in the longest distance to the projectile, did not fully strike a lung (caught the top edge of the right middle lobe), while also exiting the posterior thoracic wall without hitting a rib (between ribs 3 and 4). Shot 1 also only nicked the top of a lung lobe (top of the right inferior lobe), while not hitting a rib squarely when entering the anterior thoracic wall (nicked rib 5). Therefore, a further ANOVA was run with these two shots removed. The remaining five shots were compared to the first five shots from the 10 and $20 \%$ gelatine testing. For this data sub-set, mean distance to .223 Remington projectile was significantly affected by the target material $\left(F_{2,12}=135.09, p \leq 0.001\right)$. Tukey's HSD multiple comparison revealed that two differing levels of distances travelled by the projectiles existed; projectiles which struck the simulated thorax and $10 \%$ gelatine blocks in one level, and shots into $20 \%$ gelatine blocks in the other. The longest mean distances were in the simulated thoraxes $($ mean $=449.4 \mathrm{~mm}$, s.d. $=18.8 \mathrm{~mm}), \sim 19 \mathrm{~mm}$ greater in length than shots into $10 \%$ gelatine $($ mean $=430.0 \mathrm{~mm}$, s.d. $=13.5 \mathrm{~mm}$ ). Mean distance in $20 \%$ gelatine blocks was a further $126.2 \mathrm{~mm}$ shorter (mean $=303.8 \mathrm{~mm}$; s.d. $=12.6 \mathrm{~mm}$ ).

\section{$9 \mathrm{~mm}$ Luger projectiles}

The $9 \mathrm{~mm}$ Luger rounds perforated the gelatine blocks, regardless of concentration. The tract left by the rounds was helical in shape; there was not a 'body' of damage left. As a result, the permanent cavity damage was only assessed by measuring the fissure area that was present. The results revealed that fissure area measurements were typically greater in $10 \%$ gelatine, with the range also larger in $10 \%$ gelatine blocks (Table 3). No debris was found in any gelatine targets.

ANOVA identified that distance to the maximum expansion of the temporary cavity was not significantly affected by gelatine concentration $\left(F_{1,18}=0.16, p=\mathrm{NS}\right)$. The mean distance to maximum expansion was shorter in $20 \%$ gelatine blocks $($ mean $=248.1 \mathrm{~mm}$, s.d. $=39.9 \mathrm{~mm})$, although larger variability was also witnessed in the $20 \%$ gelatine blocks. The size of the maximum diameter of the temporary cavity was significantly affected by gelatine concentration $\left(F_{1}\right.$, $\left.{ }_{18}=21.94, p \leq 0.001\right)$. Mean maximum diameter was smaller in blocks $20 \%$ in concentration ( mean $=83.6 \mathrm{~mm}$, s.d. $=12.0$ ); temporary cavity size was over $35 \mathrm{~mm}$ larger in $10 \%$ blocks $($ mean $=110.0 \mathrm{~mm}$, s.d. $=13.1 \mathrm{~mm})$. Variability was greater in $20 \%$ gelatine blocks.

The mean distance to where $9 \mathrm{~mm}$ Luger yawed to $90^{\circ}$, for the first and second time respectively, was not significantly affected by gelatine concentration $\left(F_{1,18}=2.29, p=\mathrm{NS} ; F_{1}\right.$, $\left.{ }_{18}=1.17, p=\mathrm{NS}\right)$. Not all shots yawed three times; five shots did in $10 \%$ gelatine, and seven shots in $20 \%$ gelatine. Using this sub-set of data, gelatine concentration significantly affected the mean location of where yaw for a third time occurred $\left(F_{1,10}=0.02, p \leq 0.05\right)$. The mean distance to third yaw was longer in $10 \%$ gelatine $($ mean $=462.7 \mathrm{~mm}$, s.d. $=12.8 \mathrm{~mm})$ when compared to $20 \%$ gelatine (mean $=432.4 \mathrm{~mm}$, s.d. $=25.3 \mathrm{~mm}$ ).

ANOVA of the permanent cavity revealed that fissure area was significantly different $\left(F_{1,18}=30.15, p \leq 0.001\right)$. Mean area was less in $20 \%$ than in $10 \%$ gelatine ( $20 \%$ gelatine mean $=33,000 \mathrm{~mm}^{2}$, s.d. $=4500 \mathrm{~mm}^{2} ; 10 \%$ gelatine, mean $=49,000 \mathrm{~mm}^{2}$, s.d. $=7900 \mathrm{~mm}^{2}$ ).

\section{$9 \mathrm{~mm}$ Luger simulated thorax testing}

All $9 \mathrm{~mm}$ Luger shots perforated both the simulated thoracic cavity and the $500 \mathrm{~mm}$ gelatine block at the rear of the target. As a result, no analysis into the distance to the projectiles was carried out. Raw data collected from the interactions with the simulated thoracic cavities are presented in the electronic supplementary material. 
Table 2 Results collected from interactions between .223 Remington projectiles and simulated thoraxes

\begin{tabular}{|c|c|c|c|c|c|c|c|}
\hline \multirow{2}{*}{$\begin{array}{l}\text { Shot } \\
\text { no. }\end{array}$} & \multirow{2}{*}{$\begin{array}{l}\text { Impact velocity } \\
(\mathrm{m} / \mathrm{s})\end{array}$} & \multicolumn{3}{|l|}{ Entry location } & \multirow{2}{*}{$\begin{array}{l}\text { Distance through } \\
\text { thoracic samples } \\
(\mathrm{mm})\end{array}$} & \multirow{2}{*}{$\begin{array}{l}\text { Distance in } \\
10 \% \\
\text { gelatine }(\mathrm{mm})\end{array}$} & \multirow{2}{*}{$\begin{array}{l}\text { Total } \\
\text { distance } \\
(\mathrm{mm})\end{array}$} \\
\hline & & $\begin{array}{l}\text { Anterior } \\
\text { thoracic } \\
\text { walls }\end{array}$ & Lungs & $\begin{array}{l}\text { Posterior } \\
\text { thoracic walls }\end{array}$ & & & \\
\hline 1 & 852 & Nicked rib 5 & $\begin{array}{l}\text { Right lung, nicked the } \\
\text { top of the inferior } \\
\text { lobe }\end{array}$ & Hit rib 3 & 177 & 299 & 476 \\
\hline 2 & 851 & Hit rib 5 & $\begin{array}{l}\text { Left lung, top area of the } \\
\text { inferior lobe }\end{array}$ & Hit rib 4 & 177 & 245 & 422 \\
\hline 3 & 847 & Hit rib 7 & $\begin{array}{l}\text { Left lung, middle area } \\
\text { of the superior lobe }\end{array}$ & Hit rib 7 & 165 & 295 & 460 \\
\hline 4 & 845 & Hit rib 5 & $\begin{array}{l}\text { Right lung, nicked the } \\
\text { top edge of the middle } \\
\text { lobe }\end{array}$ & Between ribs 3 and 4 & 165 & 332 & 497 \\
\hline 5 & 840 & $\begin{array}{l}\text { Hit ribs } 5 \\
\text { and } 6\end{array}$ & $\begin{array}{l}\text { Right lung, top area } \\
\text { of the inferior lobe }\end{array}$ & Hit rib 5 & 170 & 287 & 457 \\
\hline 6 & 837 & Hit rib 7 & $\begin{array}{l}\text { Left lung, bottom area } \\
\text { of the superior lobe }\end{array}$ & Hit rib 6 & 170 & 269 & 439 \\
\hline 7 & 847 & Hit rib 8 & $\begin{array}{l}\text { Left lung, middle area } \\
\text { of the inferior lobe }\end{array}$ & Hit rib 8 & 170 & 299 & 469 \\
\hline
\end{tabular}

\section{Discussion}

\section{Gelatine}

The expansion of the .223 Remington rounds in both concentrations of gelatine produced temporary cavities that expanded beyond the diameter of the projectile on initial penetration, with no initial channel present beforehand (Fig. 3). The formation of the temporary cavities in both concentrations of gelatine followed the same pattern, supported by the result that there was no significant difference in the distance to the maximum point of temporary cavitation. Every shot was captured completely in the block (for both concentration types). The permanent cavity left in both concentrations of gelatine was reminiscent of an ellipsoid. Both the permanent and temporary cavities produced by .223 Remington projectiles were similar in shape and formation in both gelatine concentrations. However, greater damage was observed in $10 \%$ gelatine blocks; with both significantly larger temporary cavity diameters and significantly larger permanent cavity measurements recorded when compared to $20 \%$. Although $20 \%$ gelatine has a higher density $\left(1.05 \mathrm{~g} / \mathrm{cm}^{3}\right.$ compared to $\left.1.03 \mathrm{~g} / \mathrm{cm}^{3}\right)[25$, $26]$, and materials of greater density absorb more energy and thus have a higher potential for sustaining damage [23], the elasticity and gel strength also affects the level of damage. Blocks of $20 \%$ gelatine contained a higher concentration of gelatine and thus a greater gel strength $[30,31]$. The greater gel strength meant the blocks were better at resisting the disruptive effects of the temporary cavity. As a result, blocks of $10 \%$ gelatine were less efficient at containing the expansion of the temporary cavity, with less gel strength also having an effect on recovery, explaining why greater permanent damage was also produced in $10 \%$ blocks. When measurements of fissures were compared, a similar result was seen; the areas of the fissures were larger in $10 \%$ blocks, with the range also greater. This can again be attributed to the $20 \%$ gelatine having greater strength.

The $9 \mathrm{~mm}$ Luger is not designed to expand on impact; the brass-coated steel full metal jacket stops this from occurring, keeping the projectile intact as it continues through the target. This resulted in complete perforation of the $500 \mathrm{~mm}$ target blocks, regardless of the concentration of gelatine. The spin imparted to the individual projectiles designed to keep them stable during flight could be seen to fail during perforation of the gelatine targets, reaching $90^{\circ}$ yaw within the $500 \mathrm{~mm}$ blocks between two or three times before exiting. This was not a surprising result considering the effect of density on projectile stability $[20,25]$. No significant difference in the locations of where $90^{\circ}$ yaw occurred for the first and second time corroborates with the fact that no significant difference was found between the locations where maximum temporary cavity expansion occurred and gelatine concentration. This is because the temporary cavity is usually largest when the projectile expands or yaws to $90^{\circ}$; greater projected area causes greater transfer of energy to the tissues [22]. If the projectiles reached $90^{\circ}$ yaw a third time, a significant difference in location was found between the two gelatine concentrations. A potential explanation for this is that the denser gelatine produced greater resistance on the projectiles, causing greater deceleration, which in turn led to the projectiles yawing for a third term earlier within the $20 \%$ gelatine blocks.

Instead of an ellipsoid shape, a helical pattern was in $10 \%$ gelatine blocks perforated by $9 \mathrm{~mm}$ Luger ammunition. It can be hypothesised that the helical shape was a result of the spin 
Table 3 Results collected from interactions between $9 \mathrm{~mm}$ Luger and (a) 10 and (b) $20 \%$ gelatine

(a) $10 \%$ gelatine

$\begin{array}{lll}\text { Shot no. } & \begin{array}{c}\text { Impact velocity } \\ (\mathrm{m} / \mathrm{s})\end{array} & \begin{array}{l}\text { Temporary cavity } \\ \text { Distance to maximum } \\ \text { expansion }(\mathrm{mm})\end{array} \\ 1 & 422 & 276 \\ 2 & 429 & 314 \\ 3 & 429 & 277 \\ 4 & 429 & 247 \\ 5 & 431 & 225 \\ 6 & 433 & 212 \\ 7 & 435 & 252 \\ 8 & 427 & 235 \\ 9 & 425 & 281 \\ 10 & 432 & 226 \\ \text { Mean } & 429.2 & 254.6 \\ \text { s.d. } & 3.9 & 31.9 \\ \text { CV (\%) } & 0.9 & 12.5 \\ \text { Min } & 422 & 212 \\ \text { Max } & 435 & 314\end{array}$

\begin{tabular}{|c|c|}
\hline $\begin{array}{l}\text { Maximum } \\
\text { diameter (mm) }\end{array}$ & $\begin{array}{l}\text { Yaw } \\
\text { Number of times } \\
90^{\circ} \text { reached }\end{array}$ \\
\hline 113 & 3 \\
\hline 80 & 2 \\
\hline 118 & 2 \\
\hline 116 & 3 \\
\hline 117 & 2 \\
\hline 100 & 3 \\
\hline 125 & 2 \\
\hline 106 & 3 \\
\hline 120 & 2 \\
\hline 104 & 3 \\
\hline 109.9 & 2.5 \\
\hline 13.1 & 0.5 \\
\hline 11.9 & 21.1 \\
\hline 80 & 2 \\
\hline 125 & 3 \\
\hline
\end{tabular}

Total fissure area $\left(\mathrm{mm}^{2}\right)$

block (mm)

$\begin{array}{llll}243 & 301 & 466 & 41,000 \\ 318 & 367 & - & 37,000 \\ 265 & 485 & - & 53,000 \\ 266 & 311 & 475 & 60,000 \\ 215 & 402 & - & 45,000 \\ 216 & 449 & 474 & 42,000 \\ 241 & 476 & - & 54,000 \\ 223 & 275 & 448 & 59,000 \\ 298 & 348 & - & 53,000 \\ 231 & 277 & 451 & 47,000 \\ 251.4 & 369.1 & 462.7 & 49,000 \\ 35.0 & 80.4 & 12.8 & 8,000 \\ 13.9 & 21.8 & 2.7 & 16.2 \\ 215 & 275 & 448 & 37,000 \\ 318 & 485 & 475 & 60,000\end{array}$

(b) $20 \%$ gelatine

Shot no. Impact velocity

\begin{tabular}{ll}
1 & 420 \\
2 & 434 \\
3 & 427 \\
4 & 427 \\
5 & 432 \\
6 & 427 \\
7 & 420 \\
8 & 422 \\
9 & 420 \\
10 & 427 \\
Mean & 425.6 \\
s.d. & 5.0 \\
CV (\%) & 1.2 \\
Min & 420 \\
Max & 434 \\
\hline
\end{tabular}

Temporary cavity Distance to maximum expansion (mm)

318
317
219
217
220
238
249
262
236
206
248.1
39.9
16.1
206
318

$\begin{array}{ll}\begin{array}{ll}\text { Maximum } \\ \text { diameter }(\mathrm{mm})\end{array} & \begin{array}{l}\text { Yaw } \\ \text { Number of times }\end{array} \\ 71 & 3 \\ 85 & 3 \\ 76 & 2 \\ 99 & 3 \\ 87 & 3 \\ 93 & 2 \\ 79 & 3 \\ 86 & 3 \\ 99 & 2 \\ 62 & 3 \\ 83.6 & 2.7 \\ 12.1 & 0.5 \\ 14.4 & 17.9 \\ 62 & 2 \\ 99 & 3\end{array}$

Location within block (mm)

$\begin{array}{llll}285 & 347 & 476 & 34,000 \\ 247 & 297 & 447 & 30,000 \\ 209 & 440 & - & 29,000 \\ 201 & 254 & 406 & 39,000 \\ 222 & 290 & 446 & 38,000 \\ 225 & 424 & - & 37,000 \\ 230 & 292 & 409 & 36,000 \\ 234 & 284 & 426 & 31,000 \\ 226 & 418 & - & 32,000 \\ 235 & 281 & 417 & 25,000 \\ 231.4 & 332.7 & 432.4 & 33,000 \\ 22.9 & 69.5 & 25.3 & 4,500 \\ 9.9 & 20.9 & 5.9 & 13.6 \\ 201 & 254 & 406 & 25,000 \\ 285 & 440 & 476 & 39,000\end{array}$

present on the non-deformed projectile, with the larger areas of temporary cavity expansion a result of the projectiles reaching $90^{\circ}$ yaw. As a result of the helical shape, only fissure area analysis was carried out on the permanent damage produced. However, this still revealed a similar pattern to that observed with the .223 Remington projectiles; area of damage was significantly greater in $10 \%$ gelatine blocks compared to $20 \%$ gelatine blocks.

The results collected clearly displayed that a difference occurred with regards to the permanent cavity size produced when the same ammunition was tested in different concentrations of gelatine. This result, although not unexpected, does not appear to have been discussed in the open literature before. The permanent cavity left in both concentrations of gelatine was equivalent of the central zone of damage; the area damaged by the direct crushing and lacerating of tissue by both projectile types [18-20]. The calculation of the ellipsoid volume may not be an effective method for deciding the area of living tissue that should be debrided after a gunshot; that should be based on whether tissue is viable or not [21]. However, it was a consistent method for 
estimating the volume that was damaged and comparing events to see where more damage was done.

\section{Simulated torso}

Porcine samples have been used previously in ballistic testing, in the form of specific sections from whole cadavers (e.g. thigh, abdomen, thorax and neck [27]; thigh [32]; as well as in similar form to the samples tested in this trial $[28,29])$. Work conducted by Breeze et al. [32] showed that refrigerating or freezing porcine tissue followed by thawing had no effect on the level of retardation to FSPs. Although work comparing penetration depths of FSPs into $20 \%$ gelatine and porcine tissues has been carried out [27], it is believed that the current work is the first in the open literature to compare damage produced by live rounds in a simulated thorax formed of porcine samples to both 10 and $20 \%$ gelatine.

Comparing .223 Remington baseline shots into porcine tissue and both 10 and $20 \%$ blocks of gelatine revealed significant differences between all three with respect to the distance to the projectile after penetration. However, when shots which failed to strike all sections of the simulant thoracic cavity and/or the ribs were removed, a significant difference was only apparent between the distances to projectiles in $20 \%$ gelatine (in one group) and distances in both $10 \%$ gelatine and the simulated thoracic cavity (both in the same group). The fact that the thoracic cavities had a $10 \%$ gelatine block at the rear of the target and the measurement to the distance of the projectile included the distance travelled through this block is a point of discussion. This target design follows a similar setup used by Fackler et al. [4, 5], however, from which the basis of $10 \%$ gelatine replicating the penetration depth of two projectile types to within $3 \%$ of the penetration depth attained in living porcine leg muscle.

That two shots were removed in order for no significant difference to be present between distance to the projectiles in the simulated thorax, and the $10 \%$ gelatine, was a result of the inhomogeneous nature of tissues which form living organisms. When bone was struck, no significant difference was observed. One of the recommended criteria for a tissue simulant is that it is homogenous, so that factors such as location of shot do not have an effect on the results.

Comment on the temporary cavitation formation in the thorax arrangements was not possible due to the porcine samples being opaque. Therefore, the measure used in this work to compare the two different concentrations of gelatine blocks and the thorax arrangement was depth of penetration, which is a widely accepted measurable criterion used in ammunition lethality studies. However, it should be noted that depth of penetration is not the only criterion considered in lethality studies. Alternatives include energy transfer. Therefore, a limitation of this study is that the energy transfer to tissue (important factor of wounding) could not be directly captured.
The permanent damage produced in the porcine specimens was smaller in scale than that produced in both gelatine blocks. Measurements of entry and exit holes in all porcine samples were the only physical measurements taken; damage in the lungs did not typically extend past the diameters of the penetrating projectiles.

The level of debris collected from the porcine specimens was far greater when compared with the gelatine targets; the presence of solid materials (bone) in the target was the cause of this; not a surprising result. It did, however, demonstrate how the debris can spread when dense materials (such as bone) are present within a target structure that is involved in a gunshot incident. The production of secondary projectiles caused after a bullet striking bone has been reported previously (e.g. [21, 24]). No exterior targets (e.g. clothing, body armour) were struck prior to entering the target, so there was limited chance of foreign debris being brought into the damaged region to cause contamination. However, Hiss and Kahana [24] state that microorganisms from perforated tissues of the target can be spread throughout a wound, causing contamination.

\section{Conclusions}

The damage produced in both concentrations of gelatine was similar in formation for both ammunition types tested, albeit with results on a smaller scaler in $20 \%$ gelatine blocks. This is not a surprising result given the greater density and gel strength of the $20 \%$ blocks. It is of importance, however, given that both concentrations of gelatine are used extensively as tissue simulants of the human body; which is more reminiscent of a human target? Experiments utilising porcine samples to simulate a thorax found depths of penetration to be significantly different to $20 \%$ gelatine, but not $10 \%$ gelatine for expanding rifle ammunition. The level of damage produced in the thoraxes was smaller in scale to the expansion witnessed in both gelatine concentrations, though greater debris was produced in the simulated thoraxes.

Acknowledgments The authors acknowledge the assistance of Mr D. Miller and Mr M. Teagle with ballistic testing. The support of EPSRC and The Home Office are also recognised.

Open Access This article is distributed under the terms of the Creative Commons Attribution 4.0 International License (http:// creativecommons.org/licenses/by/4.0/), which permits unrestricted use, distribution, and reproduction in any medium, provided you give appropriate credit to the original author(s) and the source, provide a link to the Creative Commons license, and indicate if changes were made. 


\section{References}

1. Fackler ML, Malinowski JA (1985) The wound profile: a visual method for quantifying gunshot wound components. J Trauma 25: $522-529$

2. Jussila J (2004) Preparing ballistic gelatine - review and proposal for a standard method. Forensic Sci Int 141:91-98

3. Sellier KG, Kneubuehl BP (1994) Wound ballistics and the scientific background. Elsevier, Netherlands

4. Fackler ML, Surinchak JS, Malinowski JA, Bowen RE (1984) Bullet fragmentation: a major cause of tissue disruption. J Trauma 24:35-39

5. Fackler ML, Surinchak JS, Malinowski JA, Bowen RE (1984) Wounding potential of the Russian AK-74 assault rifle. J Trauma 24:263-266

6. Fackler ML (1987) What's wrong with the wound ballistics literature, and why. Letterman Army Institute of Research. Presidio of San Francisco, California

7. Fackler ML, Bellamy RF, Malinowski JA (1988) The wound profile: illustration of the missile-tissue interaction. J Trauma 28:s21s29

8. Fackler ML, Malinowski JA (1988) Ordnance gelatine for ballistic studies - detrimental effect of excess heat used in gelatine preparation. Am J Forensic Med Pathol 3:218-219

9. Harvey EN, McMillen JH, Butler EG, Puckett WO (1962) Mechanism of wounding. In: Coates JB (ed) Wound Ballistics. Medical Department United States Army, Washington D.C., pp 143-235

10. DeMuth WE (1966) Bullet velocity and design as determinants of wounding capability: an experimental study. Proc 11th Int Symp Ballist 6:222-232

11. Knudsen PJT, Vignaes JS (1995) Terminal ballistics of $7.62 \mathrm{~mm}$ NATO bullets: experiments in ordnance gelatine. Int J Legal Med 108:62-67

12. Wilson LB (1921) Dispersion of bullet energy in relation to wound effects. Mil Surg 49:241-251

13. Krauss M (1957) Studies in wound ballistics: temporary cavity effects in soft tissues. Mil Med 121:221-231

14. Korać Z, Kelenc D, Baškot A et al (2001) Substitute ellipse of the permanent cavity in gelatin blocks and debridement of gunshot wounds. Mil Med 166:689-694

15. Korać Z, Kelenc D, Mikulić D et al (2001) Terminal ballistics of the Russian AK 74 assault rifle: two wounded patients and experimental findings. Mil Med 166:1065-1068

16. MacPherson D (2005) Bullet penetration - modeling the dynamics and incapacitation resulting from wound trauma. Ballistic Publications, United States of America

17. Mabbott A, Carr DJ, Champion S, et al. (2013) Comparison of 10 $\%$ gelatine, $20 \%$ gelatine and Perma-Gel ${ }^{\mathrm{TM}}$ for ballistic testing. In: 27th Int Symp Ballistics. International Ballistics Society, Freiburg, p 648-654

18. Wang ZG, Tang CG, Chen XY, Shi TZ (1988) Early pathomorphologic characteristics of the wound track caused by fragments. J Trauma 28:s89-s95

19. Bowyer GW, Ryan JM, Kaufmann CR, Ochsner MG (1997) General principles of wound management. In: Ryan JM, Rich NM, Dale RF, et al. (eds) Ballist trauma - Clin Relev peace war. Arnold, New York, p 105-119

20. Ryan JM, Rich NM, Burris DG, Ochsner MG (1997) Biophysics and pathophysiology of penetrating injury. In: Ryan JM, Rich NM, Dale RF, et al. (eds) Ballist trauma - Clin Relev peace war. Arnold, New York, p 31-46

21. Janzon B, Hull JB, Ryan JM (1997) Projectile-material interactions: soft tissue and bone. In: Cooper GJ, Dudley HAF, Gann DS et al (eds) Sci Found Trauma. Butterworth-Heinemann, Oxford, pp 37 52

22. Berlin R, Gelin LE, Janzon B, et al. (1976) Local effects of assault rifle bullets in live tissue. Part I Acta Chir Scand Suppl 459:4-48

23. Belkin M (1979) Wound ballistics. Prog Surg 16:7-24

24. Hiss J, Kahana T (2000) Modern war wounds. In: Mason JK, Purdue BN (eds) Pathol Trauma. Arnold, New York, pp 89-102

25. Janzon B (1997) Projectile-material interactions: simulants. In: Cooper GJ, Dudley HAF, Gann DS et al (eds) Sci Found Trauma. Butterworth-Heinemann, Oxford, pp 26-36

26. Eisler RD, Chatterjee AK, Burghart GH, O'Keefe JA (2001) Casualty assessments of penetrating wounds from ballistic trauma. Mission Research Corporation, Costa Mesa

27. Breeze J, Hunt NC, Gibb I et al (2013) Experimental penetration of fragment simulating projectiles into porcine tissues compared with simulants. J Forensic Leg Med 20:296-299

28. Carr DJ, Kieser J, Mabbott A et al (2014) Damage to apparel layers and underlying tissue due to hand-gun bullets. Int J Legal Med 128: 83-93

29. Mabbott A, Carr DJ, Caldwell E et al (2014) Bony debris ingress into the lungs due to gunshot. 28th International Symp Ballist, Atlanta

30. Osorio FA, Bilbao E, Bustos R, Alvarez F (2007) Effects of concentration, bloom degree, and $\mathrm{pH}$ on gelatin melting and gelling temperatures using small amplitude oscillatory rheology. Int J Food Prop 10:841-851

31. Rousselot (2014) Gelatine bloom. http://www.rousselot.com/en/ rousselot-gelatine/gelatine-characteristics/definitions/gelatinebloom/

32. Breeze J, Carr DJ, Mabbott A et al (2015) Refrigeration and freezing of porcine tissues does not affect the retardation of fragment simulating projectiles. J Forensic Leg Med 32:77-83 